\title{
Magic City Killjoys: Women Organizers, Gentrification, and the Politics of Multiculturalism in Little Haiti
}

\author{
Marta Gierczyk \\ University of Miami, US \\ mdg60@miami.edu
}

\begin{abstract}
"Magic City Killjoys" is a fieldwork-based study of women of color advocacy for community justice in Miami's Little Haiti. The article draws on scholarship from urban and gender studies as well as on critical conversations about Miami's multiculturalism and blackness, demonstrating how women organizers and leaders spearhead the local anti-gentrification movement to curtail displacement and cultural appropriation. My focus on feminization of organizing in the contentious battle for Miami's future reveals the persistent and self-perpetuating gender and race imbalance between the city's grassroots and official development politics. The women organizers who populate the pages of this essay defend a community-driven process and protest the masculinist, top-down approaches to urban development, even as they don't always agree about the ways in which that protest should take place. Ultimately, I argue that thinking through the multigenerational, varied, and periodically opposed perspectives and practices within this women-led advocacy allows us to evaluate the social landscape of Little Haiti as neither politically nor economically hermetic, neither an issue to be fixed nor a culture to be consumed. Instead, the complex infrastructure of grassroots organizing reveals the Little Haiti community as entrepreneurial, politically-engaged, and economically, culturally, and generationally diverse. This image stands in direct opposition to the two-dimensional frameworks of cultural branding that index Haitian and Haitian American culture via the simplistic tropes of poverty or consumable difference and to the city of Miami's history of ignoring or repressing its Black roots.
\end{abstract}

Keywords: gentrification; Little Haiti; multiculturalism; Black Miami; women advocacy

"Miami is culture, an amalgamation of the Caribbean and Latin America" announces the promotional reel for the Magic City Innovation District Special Area Plan (Magic City SAP) in Little Haiti-released in 2018 and broadcasted on the developer's website and through social media channels. Intercutting scenes of fine dining and luxury-condo living with images of Haitian flags and folk dress, neighborhood murals, and Mache Ayisyen, ${ }^{2}$ the video inserts Haitian culture into the fantasy of Miami's affluent multiculturalism. Magic City Innovation District (Magic City) invokes Haitian heritage to promote a massive luxury development so out of scale and character of the existing neighborhood that it threatens to displace the very community the promotional teaser claims to celebrate. ${ }^{3}$ The use of Black culture as a draw for tourists and a catalyst for

\footnotetext{
Special Area Plan (SAP) is a provision named after a section of the Miami 21 zoning code which allows developers who assemble nine consecutive acres of land to apply for a land-use change. Throughout this essay, I will use the abbreviation Magic City SAP to refer to the project itself and Magic City to refer to the developer.

${ }^{2}$ Little Haiti's Mache Ayisyen, also known as The Caribbean Marketplace, is the largest venue space within the Little Haiti Cultural Complex. The Marketplace is mostly used as a space for vendors selling Caribbean and African goods and products. The building that would become the marketplace was originally constructed in 1936. In 1984 architect Charles Harrison Pawley won the design competition to repurpose the building. Pawley's design of the Marketplace was inspired by "Marchè en Fer" the Iron Market in Portau-Prince, and the gingerbread house architecture in Haiti. The Marketplace opened in 1990 and closed just nine years later due to structural and financial problems. Community protest saved the structure from being demolished in 2005. Remodeled since then, the Marketplace obtained "Florida Heritage Site" designation in 2018.

${ }^{3}$ According to the environmental impact study by Earth Economics-a Tacoma, Washington-based nonprofit research organization-the Magic City Innovation District could displace more than 3,000 households in Little Haiti. The study was commissioned
} 


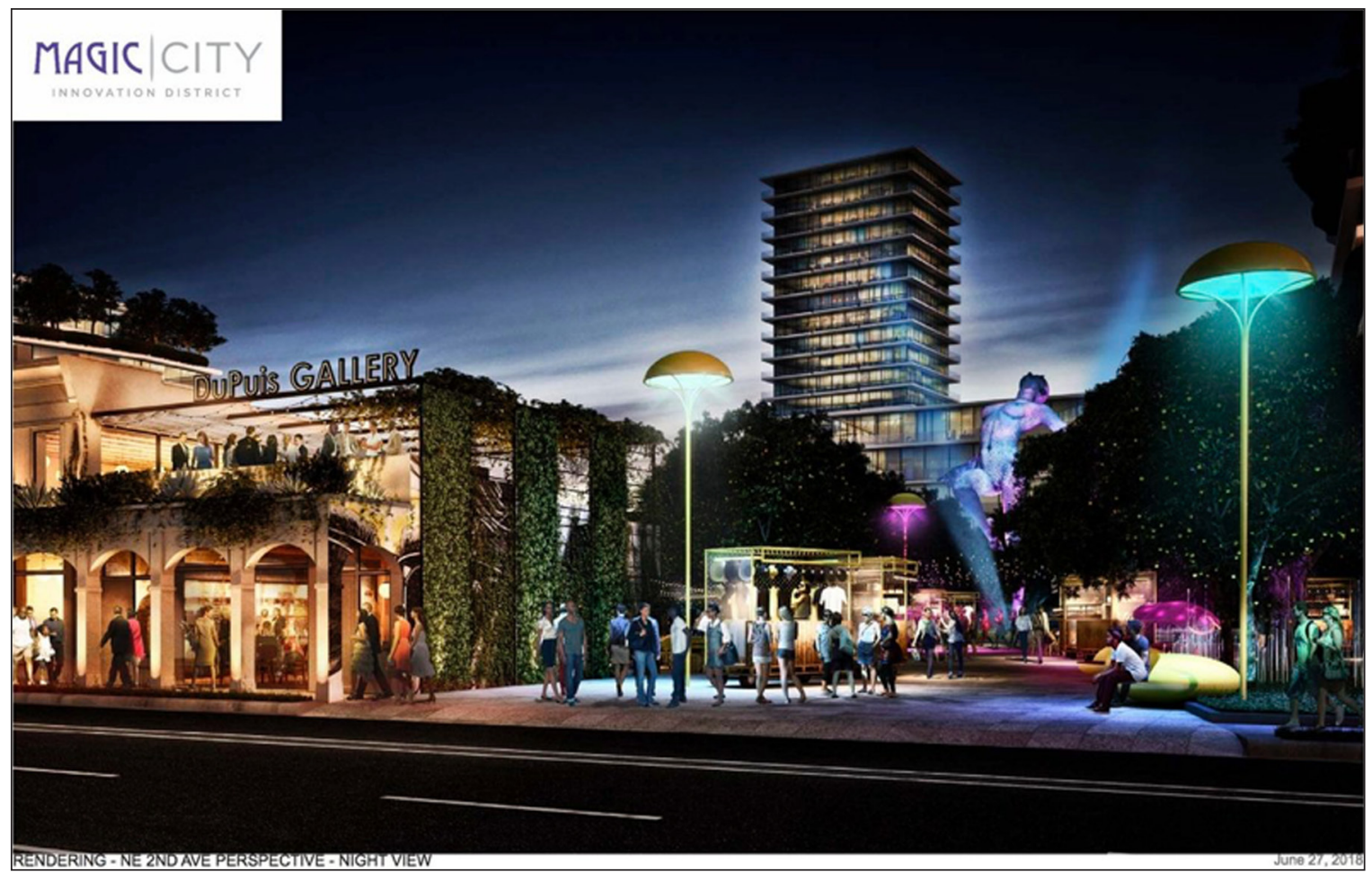

Project images from Magic City developers for the proposed multi-use luxury complex in Little Haiti. Photo credit Magic City website.

neighborhood redevelopment represents a significant change in gentrification strategies in Miami. ${ }^{4}$ Marketers have long deployed the city's Caribbean networks to sell real estate and vacation dreams, in the past relying primarily on images of and connections to a white multinational Latino identity. However, in the last decade Miami's development and tourism industries, such as the Greater Miami Conventions and Visitors Bureau, have seized Haitian culture as the new darling of the city's cultural branding with initiatives like the 2011 Biscayne Boulevard "hidden gems" tours and the 2014 "It's so Miami: People and Places" campaign. ${ }^{5}$ This celebration of Haitian heritage can only masquerade as progress when compared to decades of crude devaluation of Afro-Caribbean contributions to Miami's multicultural landscape.

Between Little Haiti's newly-appreciated (or frankly, appropriated) symbolic cultural capital, the neighborhood's centralized location in Miami-Dade's geography, and its precious high-ground topography, the area has been gentrifying with a scope and speed dizzying even by the standards of Miami's development history, which brought about the town's famous Magic City nickname. The use of ethnic culture as a tool of neighborhood redevelopment-what I refer to as cultural branding-has become the favored medium for urban planners and marketers. ${ }^{6}$ Throughout the essay I suggest that there is a fine line between cultural branding as a shield against gentrification and cultural branding as a tool of gentrification. Making a culture more accessible and more recognizable, even at a grassroots level, often requires a certain level of simplification and highlighting of the consumable elements of culture and history-what Arlene Davila

by groups opposing Magic City: Community Justice Project and FANM. While Magic City challenges the study, they did not seek to provide an alternative displacement study (despite community requests).

${ }^{4}$ Throughout the essay, I use the term culture in its narrow sense as a manifestation of ethnic and racial identity (in architecture, art, music, food, language, etc.).

${ }^{5}$ In 2011, the Urban Environmental League hosted a visitors' tour showcasing the "developing neighborhoods around Biscayne Boulevard" (rfc.museum/images/stories/archive/20110210-miamiherald.pdf). The Little Haiti farm was one of the stops on the tour. A couple of years later the Greater Miami Convention \& Visitors Bureau (GMCVB) announced the launch of the "It's So Miami (ISM): People and Places" (2013-2015) campaign, offering an "in-depth and authentic look at the rich cultural capital of "Miami's heritage neighborhoods" from the local insiders. The initial series featured short promotional clips for neighborhoods: Little Havana, Coconut Grove/Village West, Overtown, Little Haiti. The clips can be viewed at www.miamiandbeaches.com/ neighborhoods?utm_source=Vanity_URL\&utm_medium=itsomiami.com.

${ }^{6}$ Cultural branding is a process of formalizing and amplifying versions of ethnic identity for purposes varying from cultural preservation to profit-oriented marketing. This might include beautification of an area through heritage-oriented art, festivals, cultural institutions and heritage museums, historic designations for landmarks, and the like. 
calls "marketable ethnicity" (11). The strategy of cultural branding often emerges from within the community to promote inclusion, prevent cultural erasures, and redress the tired tropes of crime-ridden spaces in need of restoration or empty spaces in need of cultivation. But the outward-facing approach often ends up exacerbating the issue of dispossession that grassroots cultural branding seeks to resolve. The case of cultural branding in Little Haiti reflects the ways that this process can be co-opted to prioritize tourists and broader city audiences, advancing a "heritage neighborhood" narrative developers can easily exploit for profit. Magic City's seemingly celebratory framework presents Little Haiti's cultural richness as a mismanaged asset needing outsider money, expertise, and vision to thrive. The developer's cultural branding tactics promote top-down development as a lifeline for the culture-rich but resource-poor immigrant neighborhood, monopolizing on the narrative of a hapless and homogenous community that is inept at managing its own cultural capital and incapable of producing its own transformation.

In contrast, Little Haiti's de facto poet laureate and long-time inhabitant Edwidge Danticat waxes poetically on the same tropes of murals and music. As a cultural insider, her recitations of the "soul of Little Haiti" - the konpa ${ }^{7}$ and gospel, the smells of delectable foods, the churches and the botanicas - relate an authentic engagement with the neighborhood articulated in an ethos of care that recognizes the long history of cultural production and politically-active Miami citizenship for the diasporic residents of the neighborhood (Danticat, "The Soul of Little Haiti"). Writing on the survival and survivance of a people continually displaced, she reflects the attitudes of a collective endeavor by multigenerational women organizers and leaders in Little Haiti to resist the dispossessions of twenty-first century gentrification and capital encroachment. By thinking through the multiple, diverse, and periodically opposed views and practices within this women-led advocacy for neighborhood justice, I argue that we can evaluate the social landscape of Little Haiti as neither politically nor economically hermetic, neither an issue to be fixed nor a culture to be consumed. Instead, this complex infrastructure of grassroots organizing reveals the Little Haiti community as entrepreneurial, cosmopolitan, politically-engaged, and economically, culturally, and generationally diverse; this image stands in direct opposition to Magic City's two-dimensional representations of Haitian and Haitian American culture and to the city of Miami's history of ignoring or repressing its Black roots.

\section{Magic City Killjoys: A Framework}

In Eloquent Rage, Black Feminist Brittney Cooper, through the lyrics of Beyoncé, theorizes "what it means for women's bodies to keep the tempo of social movements" (27). The women addressed in this essay keep the tempo of protest against a top-down urban development that results in cultural appropriation and asset annihilation, even as they disagree about the ways in which that protest should take place. Here I seek to articulate the ways in which these women occupy spaces of contention to the masculinist politics of neocolonial dispossession in Little Haiti, the ways their bodies can be interpreted as unruly or disruptive while also being ghosted from official narratives. As I illustrate, when Black women assert themselves in the public arena of development debates to expose issues with current redevelopment trends in the city, they are cast off as problematic and sensational. They become, I suggest, "killjoys" based on Sara Ahmed's observation that "[w] hen you expose a problem, you pose a problem. It might then be assumed that the problem would go away if you would just stop talking about it or if you went away" (Ahmed 37). ${ }^{8}$ The multigenerational narrative of Little Haiti's resistance illustrates that keeping the tempo requires a long-term investment in killjoy practices. This position involves a constant, tireless effort to reiterate-in ways explicitly outside of presumed frameworks of gender roles and respectability-their opposition to the current redevelopment and gentrification process, to speak for their communities even when those to whom they speak would rather not listen.

The role of women organizers in Miami's development remains understudied in popular accounts and scholarship alike, and my focus on the feminization of grassroots organizing reveals the persistent and self-perpetuating gender imbalance in Miami's development politics. ${ }^{9}$ Women have long led the way in

\footnotetext{
${ }^{7}$ Konpa (also spelled compas) is a musical genre that originated in Haiti in the 1950s. It is sometimes referred to as a Haitian merengue.

${ }^{8}$ The term feminist killjoy was coined by Sara Ahmed in her 2010 book The Promise of Happiness. Ahmed reclaims as empowering the figure of a killjoy who challenges the problematic status quo by calling out the casual instances of racism, misogyny, or classicism. This refusal to be complacent, this killing of oppressive norms masquerading as joy can occur at a family dinner, or when one points out a racist joke during a friend's gathering or at a workplace, but also in the media or public spaces. Ahmed discusses the figure of a killjoy alongside the "unhappy queer," "angry black woman," and the "melancholic migrant" to problematize the drive for undisturbed "happiness." The term was inspired by Ama Ata Aidoo's 1977 prose-poem "Our Sister Killjoy."

${ }^{9}$ In All You That Labor, Melissa Snarr uses the term "feminization of organizing" when analyzing the role of women in the Living Wage Movement.
} 


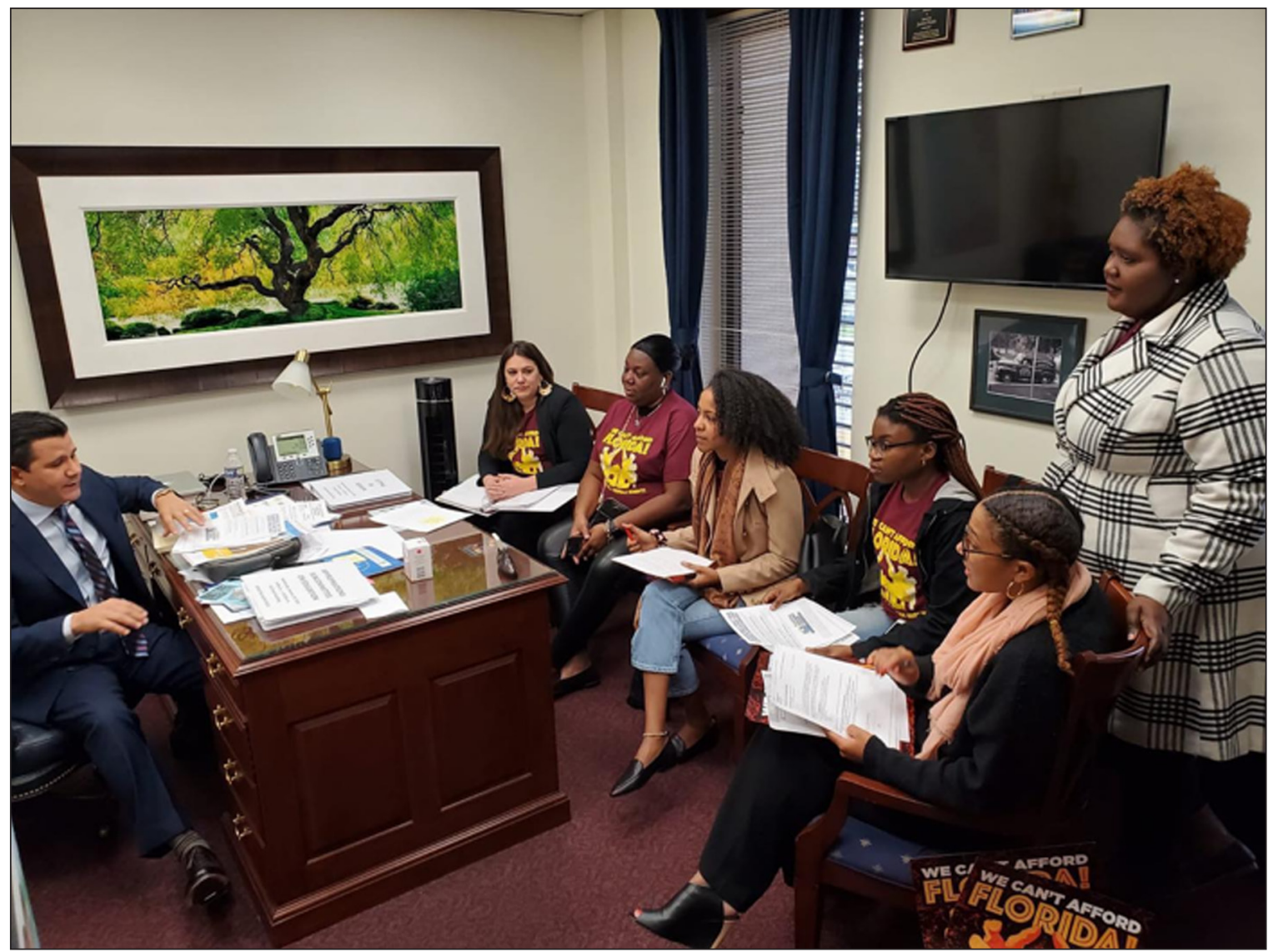

Magic City killjoys meeting with senator Jason Pizzo at the 2020 Legislative Week in Tallahassee to discuss the housing affordability crisis in Miami; January 2020. From the left: Alana Greer, CJP; Trenise Bryant, Miami Workers Center; Sagine Taluy, FANM, Jessica Saint-Fleur, Engage Miami, Denise Ghartey, CJP, and Francesca Menes, CommUnity Strategies, LLC. Photo courtesy of FANM.

grassroots organizing around the issues of housing, equitable development, and resiliency, yet continue to be underrepresented among architects, urban planners, and city commissioners, and excluded from the traditional urban planning processes. ${ }^{10}$ The robust local media reporting on climate-change gentrification in Little Haiti or Liberty City acknowledges the leadership of women advocates and community movers, but this coverage does so without an analysis of how gender dynamics matter in Miami's development politics and in grassroots organizing at large. While female organizers and leaders in Little Haiti are then not absent from these discussions, it is as if their identity as women was inconsequential, as if the visible gender imbalance between Miami's grassroots and official development politics held no weight.

But gentrification is a gendered issue. Matters of public space and housing insecurity issues affect women in distinctive ways because of the central role that women still play in social reproduction and care work, and due to domestic violence and the persisting wage gap that particularly affects women of color. From the 1990s, scholarship has focused on women as agents of gentrification, highlighting the ways in which women moving into cities to participate in paid labor have restructured the city for different gender relations or expedited gentrification processes. The more recent studies also elucidate how images of women and families are used to promote the gentrification narratives of a safe city (Bondi, 1991; Lees, 2008; Kem 2010; Berg 2012). Much of this literature on gender and gentrification focuses on white women gentrifiers, foregoing discussion of women of color who have long lived an organized in the cities. Sociological works on gentrification as well popular discussions and the rhetoric of development proposals tend to also frame Black and Latinx women as either sources or victims of urban decay. Refusing such facile representations, this essay amplifies the ways in which women in Little Haiti tirelessly and unapologetically spearhead movements for neighborhood justice and intervene in urban policy-making. I join here the still limited scholarship on women-led

${ }^{10}$ See "Women Will Rebuild Miami" in The Gendered Terrain of Disaster by Elaine Enarson and Betty Marrow for a study of Miami's women organizing after Hurricane Andrew. 


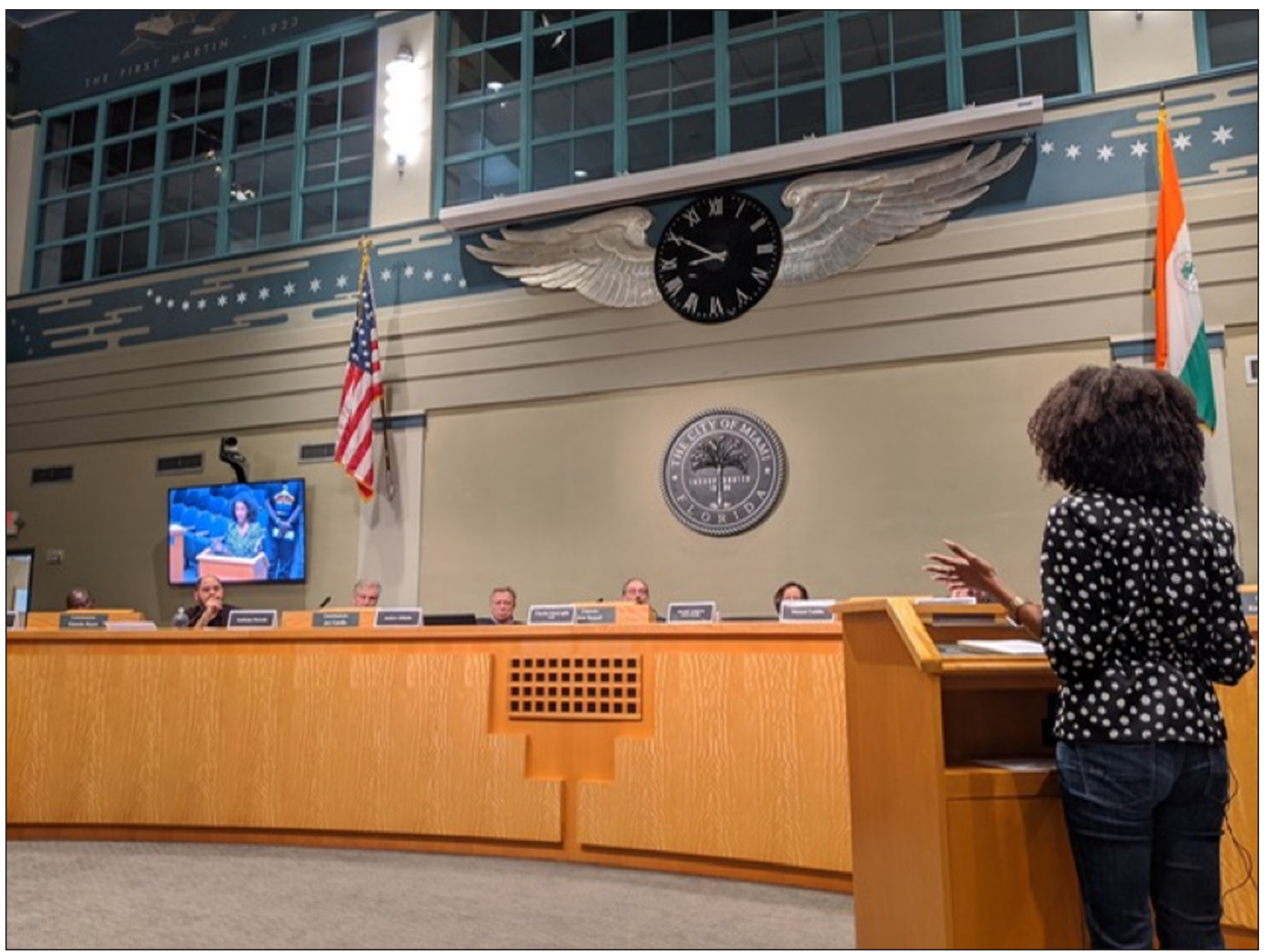

Sagine Taluy, FANM speaking at the PZAB meeting, December 4 2019. Photo courtesy of Community Justice Project.

housing and land advocacy, including Keisha-Khan Y. Perry's Black Women Against the Land Grab: The Fight for Racial Justice in Brazil discussing women-driven resistance against land expulsion in the neighborhood of Gamboa de Baixo in Salvador, as well as Roberta Feldman and Susan Stall's The Dignity of Resistance documenting the decades-long activism of African American women to counter disinvestment in public housing in Chicago. Caitlin Cahill's participatory research with young women in New York City's Lower East Side has also influenced this study; Cahill argues that the stereotypes of low-income women of color as promiscuous, lazy, uneducated, and burden to society play an important role in promoting gentrification by moralizing displacement (337). In Miami, the challenges of navigating the city's housing affordability crisis are the more pronounced for women of color who have to additionally contend with the hyper-sexualized image of "Miami girls" and the gendered and raced stereotypes of sex workers, teen moms, and welfare queens, which have been used to justify displacement of low income communities as urban problem- solving. A quick look at Miami marketing campaigns, from the 1978 "Miami: See It Like a Native" to the 2014 "pop-up pool event," illustrates how the development and tourism industries exploit the beach-and-beauty images of young women. ${ }^{11}$ The infamous 1978 poster centered the naked back of a female snorkeler wearing only a bikini bottoms with the "See it like a native" headline running under her buttocks, using the female body as an adornment to rebrand Miami as young and alluring. Following a protest from killjoys of the 1970s, the poster was eventually banned by the very tourism board who first commissioned the campaign. Over thirty years later when the image of Miami as a sexy city has been well-solidified, the Greater Miami Convention \& Visitors Bureau's "It's So Miami" campaign included an experiential component-a pop-up pool party in the middle of Union Square where models clad in "It's So Miami" bikinis danced, swam, and handed out drinks to passersby. Both campaigns sell the sun-kissed female flesh as a Miami asset in their "cultural

${ }^{11}$ The "Miami: See It Like a Native" poster was designed and circulated by the Beber Silverstein agency hired the Dade County Commission and our county tourism board. The agency explained that featuring the model Gail Kelly posing with bare bikini back was meant to help Miami break out of the retirement community image. The ad prompted feminist protests and was eventually banned. communitynewspapers.com/cutler-bay/miami-see-it-like-a-native/. 
insider" approach, reducing Miami women to a sexualized tourist attraction. On the flip side of things, developers invoke and disparage female sex workers to advance the narrative of gentrification as progress in Miami's economically struggling neighborhoods. An interview with Miami-based developer David Lombardi in the documentary The Right to Wynwood provides one appalling illustration of how development aims to remove sex workers and other low-income women from gentrifying spaces. ${ }^{12}$ Boasting on camera about his contribution to the transformation of Miami's Wynwood neighborhood into a world class arts and entertainment district-"I like to say that I took chicken shit and made chicken salad"-he invokes prostitutes as the representative figures of a "crime-ridden neighborhood." These popularized urban figures make Miami women at once hyper-visible and underrepresented in the city's official urban planning.

It is from within these realties that the Miami killjoys build political capacities; the women addressed here strategize and speak up in front of the all-male city commission, the nearly all-male planning and zoning department, and the all-male developers and investors to ensure that people who live and work in Little Haiti get a say in the redevelopment process of their own neighborhood. And in this process, they find themselves having to carve out space for their input out of the persistent gendered and racialized restrictions in the Miami's formal development politics. Defending a community-led development process, these killjoys not only challenge developers or call out elected officials but also push against one another's views and visions. They get in the way of the presumed, and imposed, uniformity. Examining organizing in Little Haiti from a multiplicity of viewpoints allows for a voicing of the elided women's narratives in the contentious battle for Miami's future through the recognition of its past.

\section{Fieldwork Methodology}

The story told here is not an ethnography of Little Haiti, but an accounting of women's advocacy for neighborhood justice through interviews, observations, and other forms of immersion, exercising a methodology that Shalini Puri terms "literary fieldwork"(40). ${ }^{13}$ This fieldwork centers subjective narratives and contextualized knowledge to examine what Lara Putnam theorizes as "the value of unsystematic, context-specific learning that does not seek the generalizable but instead the place-specific, the particular, the ungeneralizable" (178). Much thinking about the role of race and ethnicity in urban planning comes out of the social sciences and analyzes supposedly representative, comparable data. But plenty is lost-discarded as peculiar and hence unimportant-in such methodological commitment to objectivity. I advocate here for the urgency of studying culture-driven gentrification in Miami through a series of embodied encounters, in which women's personal narratives salvage intimate ways of seeing as a route to a more textured knowledge of the politics of development and multiculturalism in the city.

I rely on data collected during and in the aftermath of the contentious approval process for the Magic City SAP. Throughout this time, I have attended women-led community meetings and housing advocacy sessions, as well as City of Miami commission hearings and Planning and Zoning Advisory Board meetings. In the course of my fieldwork, I conducted a dozen formal interviews that could be categorized as unstructured and semi-structured by the scientific models. For each of the sit-down, prescheduled interviews, I used an interview guide, which grouped and outlined questions and topics to cover and included a similar set of questions for all interviews, tailored to the context. I also planned for plenty of flexibility in how my questions were formed and at what point they occurred, allowing my respondents to express themselves at their own pace and using their own terms. Some interviews were held in offices while other happened over lunch or coffee in public spaces.

But over the span of two years as a participant-observer, I have also informally interviewed many others, gathering data through conversations with community members during commission hearings, town halls, community meetings, and cultural events, with the full transparency of being a researcher. I have sought to talk to a diverse group of stakeholders in Little Haiti-leaders, advocates, business owners, and artists-who organized around the approval process for the Magic City SAP. This included long-term resident organizers who either still live and work in Little Haiti or who had lived in the neighborhood for years before moving

\footnotetext{
${ }^{12}$ The Right to Wynwood is an investigative-documentary about gentrification of Miami's Wynwood neighborhood directed by Camila Álvarez and Natalie Edgar. The film premiered at the Student Film Festival held at the Wolfsonian-FIU museum in 2014; it can be viewed on Vimeo and Youtube.

${ }^{13}$ This essay is a part of a larger project that moves between the disciplined close reading of Afro-Caribbean literature in Miami and the engagement with material realties of everyday urban life in the city. I deliberately refer to the practice at the heart of this essay as "fieldwork" to differentiate it from anthropology's social science-centered practice of "ethnography," which requires long-term immersion in place.
} 
to North Miami or Miami Shores but continue to have organizational or business ties in the community; current residents who have moved to Little Haiti in recent years and started businesses or work for local social justice organizations; and young people who grew up in Little Haiti, moved away, and have come back.

This essay highlights the voices that most vividly represent the multigenerational and culturally and politically diverse perspectives within the women-led organizing for community justice in Little Haiti. Most of the organizers who appear on the pages of this essay are Haitian American, but there are also women of Jamaican, South Asian American, and Latin American origin. Some of the main players in the debates surrounding the recent debates on Little Haiti gentrification have included: Marleine Bastien, executive director at Fanm Ayisyen Nan Miyami/ Haitian Women of Miami, known today as Family Action Network Movement (FANM); Sagine Taluy, a community organizer at FANM; Gepsie Metellus, the executive director at the Sant La Haitian Neighborhood Center; Leonie Hermantin, director of development at Sant La; Rosslyn Wuchinich, president of Unite Here Local 355; Meena Jagannath and Alana Greer, human rights lawyers at the Community Justice Project (CJP); Sandy Dorsainvil, director of the Little Haiti Cultural Center (LHCC) and former community liaison for Magic City; and Jessica Saint-Fleur, a community organizer at Engage Miami. ${ }^{14}$ The essay centers two long-term, established community leaders in Little Haiti who found themselves on the opposite sides of the Magic City SAP debate-Dorsainvil and Bastien-as well as younger anti-gentrification advocates of Haitian decent-Sagine Taluy and Jessica Saint-Fleur-and relative cultural outsiders like Meena Jagannath who advocate for their adopted neighborhood community. Despite multiple attempts to contact the chief female members of the Concerned Leaders group who spoke in favor of the Magic City SAP proposal, I was unable to obtain interviews with them. ${ }^{15}$ As a result, the majority of my interview responders represent opposition to the project. As I seek to give equal weight to the arguments on both sides, I supplement the data from interviews with quotes recorded during commission hearings. In other places, I bring to the forefront Sandy's voice as representative of proponents in favor of the project. This diverse, multigenerational, and at times quarrelsome group of women who participate in the remaking and defending of their community seek to defy the gentrification narratives that index Little Haiti via the entwined tropes of dispossession and consumable difference. Their eclectic advocacy allows us to imagine the neighborhood beyond the ontology of abjection too often assigned to Haiti and Haitians in the diaspora. Popularized gentrification and anti-gentrification narratives also hinge on an artificial binary between the developer and a monolithic community. As the Little Haiti killjoys build their political capacities outside the formal platforms, they contend with a reality of political heterogeneity and friction within the neighborhood community. Telling the story of organizing in Little Haiti in this multiplicity of viewpoints troubles the simplistic notion of frictionless solidarity and presumed unity along ethnic and class lines.

\section{Miami, the Magic City}

Though envisioned and organized by the "Mother of Miami" Julia Tuttle, Miami was designed and is still run by men. Speculative, socially-irresponsible development has defined the city's expansion since Tuttle persuaded magnate Henry Flagler to expand his railroad to Biscayne Bay in exchange for land. In A World More Concrete, Nathan Connolly traces the origins of Miami's Magic City nickname to this arrival of big money from the North in the early 1900s. These early investments transformed the area, "as if by magic," from a sprawling wilderness to a fully developed city in just a few years: "Publicists and business people agreed to call Miami the Magic City as a way of capturing the almost supernatural speed with which the developers built a city out of what seemed like thin air" (Connolly 20). What seemed like thin air was of course the tireless labor of Black migrants from the Bahamas, other Caribbean Islands, and the southern United States, an immense ecological sacrifice, and the eviction of the remaining Seminoles who still lived and traded in South Florida. In Connolly's assessment, contemporary gentrification makes for the latest chapter in the same urban story, manifesting the most durable elements of systems invested in racial and class segregation of urban spaces.

\footnotetext{
${ }^{14}$ The Family Action Network Movement assists new immigrants into South Florida by providing services especially to women and children, www.fanm.org/; founded in 2000, Sant La Haitian Neighborhood Center is a non-profit organization dedicated to "Empowering, Strengthening, and Uplifting South Florida's Haitian Community," www.santla.org; Unite Here Local 355 is South Florida's hospitality workers' union, www.unitehere355.org; Community Justice Project is a Miami-based group of human rights attorneys providing legal services to social justice movements, communityjusticeproject.com; Engage Miami is a group powered by young Miamians organizing "to build a more just, democratic, and sustainable Miami by developing a local culture of civic participation for young people that is bold, creative, and impactful," engage.miami.

${ }^{15}$ Concerned Leaders of Little Haiti/Ti Ayiti Inc is a coalition of Haitian American stakeholders in Little Haiti formed in 2018 to provide the community a united front in negotiations with the Magic City developer.
} 
As a minority-majority county (over 65\% Hispanic/Latino but overwhelmingly white identifying and over $50 \%$ foreign-born) with an extraordinary ethnolinguistic diversity, Miami figures in the popular imagination as a hyper-diverse, immigrant-friendly city at the crossroads of the Americas. Despite this seeming exceptionalism of institutionalized linguistic and cultural diversity, the city has been ailed by the same disparities of class, race, gender, and citizenship that stratify communities across urban America. The politics of Miami's felicitous multiculturalism, which imply openness and receptiveness to otherness, have worked to downgrade the issues of inequality, fragility, and racial/class fragmentation of Miami's civic society, seen most significantly in: a) clashes between Miami's long-standing African-American community and incoming immigrant groups over scarce resources; b) the built environment and real estate relations that still reflect the city's Jim Crow segregation and the New Deal's bulldozing of Black neighborhoods; and c) the complexity of overlapping migrations representing very different immigrant experiences, as the white Cuban immigrant experience has been distinctly different not only from the Haitian or Puerto Rican experience, but also from Black Cuban immigrant experience.

The carefully crafted ethos of Miami's multiculturalism, generated specifically in relation to the Cuban migrations, has long worked to uphold systems of inequality favoring Cubans. George Yudice argues that the entertainment, tourism, and development industries have all relied on the image of middle-class multinational white Latinness to promote and profit from visions of urban restructuring that result in material displacement and cultural erasure in Miami's historically Black spaces of Overtown, Liberty City, and Little Haiti (37). At the 2018 "Mapping Creole Miami" symposium, convener Donette Francis framed the conversations about Black Miami as juxtaposed to the ways in which white Latinness has become the operative logic of whiteness in Miami. She notes, "Miami has acculturated into a Spanish-dominant, bicultural city in which the upper and middle-class white Hispanic population normalized the idea and practice of a cosmopolitan hemispheric creole whiteness rather than assimilating successive generations of immigrants into a U.S.national Anglo model of 'becoming American.'" Connolly, Francis, Marvin Dunn, and other scholars of Black Miami center and amplify the long-standing and diverse Black experience in multicultural Miami, which has seemingly outgrown the Caribbean City status and yet continues to rely on its, as Francis described, "Caribbeanness as value-adding amenity." The development and tourism industries have leveraged the commercial advantages of Miami's felicitous multiculturalism, essentializing and simplifying the complex cultural and ethnic fabric of Miami. As the potency of Cuban cultural branding reached its inevitable end once Miami transformed into a Cuban majority, developers have now turned to different Caribbean ethnicities for their marketing schemes, taking up Haitian culture as the new Miami "other."

Building on these conversations about Miami's multiculturalism and blackness, I outline how the development industry, now spent on the novelty of the Cuban narrative, manipulates Haitian culture to promote gentrification of the Little Haiti neighborhood. When covering the recent redevelopment debates, news outlets invoke both the unique cultural richness and the forty-six percent poverty rate in Little Haiti-the highest in South Florida. ${ }^{16}$ These figures appear both from those supporting private investment in Little Haiti and in reports wary of gentrification-led displacement. It is critical to acknowledge and understand the decades of systemic disinvestment driving poverty and marginalization in Little Haiti; no responsible development can happen without a grasp of these numbers and the history behind them. But consuming poverty as the single story of Little Haiti, and dispossession as the very thing that defines its community, reinforces some of the most denigrating stereotypes about Haitian American spaces and people. These portrayals make use of the Caribbeanness of Haitian culture as new social capital in Miami while also employing that same Caribbeanness as symbolic of economic instability.

\section{Making and Remaking Little Haiti}

Haitian refugees first began to settle in South Florida in large numbers after Francois Duvalier came to power in 1957. Between the late 1970s and early 1980s, roughly 60,000 Haitians arrived to the Miami area fleeing political persecution and seeking economic opportunity. They concentrated in the area to the northeast of downtown Miami known as Lemon City-later dubbed Little Haiti. The narrative of Little Haiti's origins repeated to me over the span of interviews with community leaders, organizers, and residents was one of resilience and determination. Upon release from Krome and other detention centers following President Jimmy Carter's creation of the Cuban/Haitian entrant category of classification, Haitian refugees, unlike

\footnotetext{
${ }^{16}$ See for example: "Some 40 percent of residents live below the federal poverty level" (Vigluccit); "the time is ripe for the aging and more run-down parts of Little Haiti, one of the poorest areas of Miami" (Luscombe); "in a (Little Haiti) neighborhood with a high poverty rate and a large minority population" (Bandell).
} 
their Cuban counterparts, were left with little to no government assistance, faced anti-Black racism combined with anti-Haitian prejudice, and clashes with African Americans over scarce resources. ${ }^{17}$ Despite these challenges, Haitians in Miami developed their neighborhood into a vibrant, if still economically struggling, enclave economy with a strong small business ecosystem and institutional infrastructure.

Since the earliest migrations, newcomers from Haiti relied on organizing from within the nascent community to deliver services not authorized by the local and federal governments. The Haitian Refugee Center (HRC) provided legal services for incoming refugees. ${ }^{18}$ Local churches-most notably Notre Dame d'Haiti Catholic Church-additionally supported the newly-forming diaspora by facilitating community building, advocacy, and welfare work. ${ }^{19}$ While faith-based organizations and initiatives were led by men like Father Gérard Jean-Juste and archbishop Thomas Wenski, the majority of the long-standing secular grassroots organizations in Little Haiti have been spearheaded by women. The deep investment of the Catholic church in upholding patriarchy as well as the role Black churches played in advancing the politics of respectability that constrained women's social roles might explain why female advocacy focused on secular operations. Women-led groups have been instrumental in advocacy for Little Haiti's economic development, cultural preservations, and anti-displacement activism among the neighborhood's transformational community organizing practices. Women's leadership in the neighborhood seems natural to many community members, as Sandy Dorsainvil notes, "we are a matriarchal community; women sort of run the household, and most of our leaders in our community are female" (personal interview, 20 November 2019).

While published scholarship on Miami development has rarely foregrounded gender, a handful of studies highlight important moments throughout Miami's history when women asserted their political force in the male-dominated civic culture and electoral politics of the city. Melanie Shell-Weiss's book Coming to Miami: A Social History documents the contribution of "ordinary" women in the making of Miami and the "womanist strategies" that early Miami women, who were excluded from voting and other forms of civic participation, asserted to participate in the shaping of civil, political, and social life in the city (17). For example, Weiss delineates a landscape of inter-racial affinities in the early days of Coconut Grove: white and black women worked together to establish the first churches; they helped to care for each other's children, shared cooking responsibilities, and exchanged household advice; black and white pioneer women cooperated and shared within the early Grove community. Nathan Connolly's account of the influential Black female property owner Florence Gaskins as an early organizer of black women's activism during Miami's incorporation in the 1890s also provides crucial historical context for my discussion of narratives about real estate in Miami. Gaskins's approaches to community uplift through private property as a shield against racism help to situate one branch of current community advocacy that roots itself in a belief that "broader economic growth could improve living conditions for everyone" (Connolly 27).

There is an observable blurring of lines between public and domestic spheres in the way women reinvent forms of civic participation-an insistence that in matters of gentrification the personal and the political are intimately linked. The strategies of the earliest women in Miami illustrate a legacy of women-led grassroots organizing that the Magic City killjoys enter into in the twentieth and twenty-first century, and their activism is marked by the womanist approaches of "outrageous, audacious, courageous, or willful behavior [and] wanting to know more and in greater depth than is good for one," as described by Alice Walker (14). Some of the most active cultural and social organizations in the neighborhood founded and run by Little Haiti's women activists employ these womanist strategies. Co-founded by Gepsie Metellus, who also worked with HRC, Sant La focuses on education, advocacy, and documentation. Founded by Marleine Bastien in 1991, FANM has worked to economically, socially, and politically empower Haitian women and their communities across Miami. Presided over now by Michelle Cilien, the Little Haiti Housing Association-today the Haitian American Community Development Corporation-was formed in 1987 to create affordable housing opportunities for residents in the Little Haiti neighborhood. The organization currently provides various housing services, including homebuyer counseling and tenant education. In one striking difference between the cityorganized and the killjoy-organized platforms for civic engagement in the Magic City SAP debates, the latter consistently offers childcare, interpretation, and food to foster inclusion. All of these organizations share a focus on community building and community uplift by addressing the basic needs critical for daily life such as housing, education, food, transportation, and work. Women focus on the sites and processes of social

\footnotetext{
${ }^{17}$ Krome Service Processing Center is an immigration detention center, an ICE facility located in west Miami-Dade County.

${ }^{18}$ The Haitian Refugee Center was founded in the mid-1970s and offered legal assistance to Haitian refugees (Rey and Stepick).

${ }^{19}$ Notre Dame d'Haiti Catholic Church opened in the 1980s after moving from St. Mary's Cathedral to better serve the influx of new Haitian immigrants.
} 


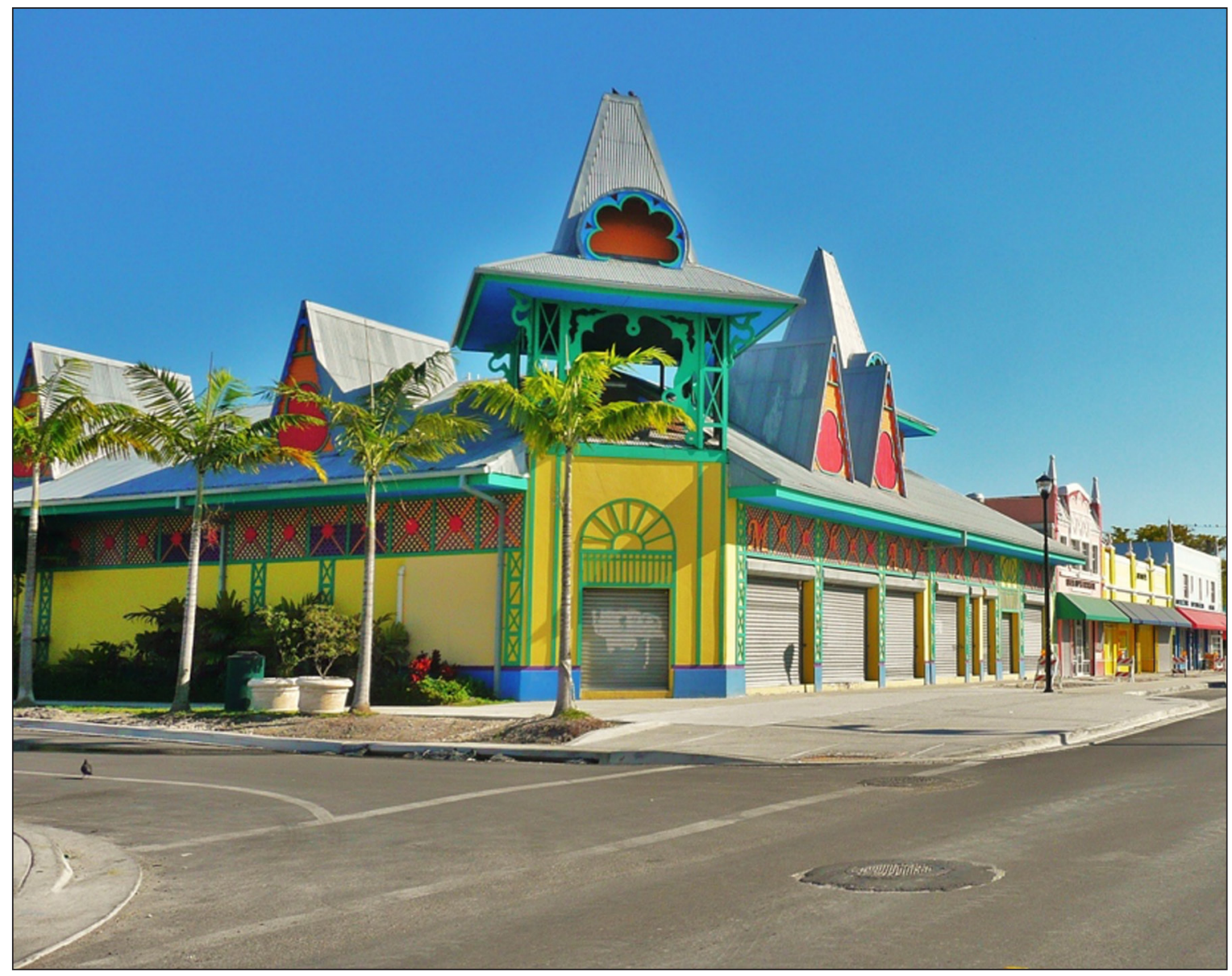

Mache Ayisien as part of the Little Haiti Cultural Complex-one of the first large-scale development projects in the Little Haiti neighborhood.

reproduction because the role of a primary caregiver (to both children and elders) still disproportionately falls on women regardless of their professional career status. ${ }^{20}$

Though Haitian refugees faced many disadvantages in establishing themselves in Miami, local initiatives by tireless community members built Little Haiti into a dynamic and supportable network. However, the outpacing of wealth growth for other immigrant groups in Miami and the influence of continued narratives of disrepute, often tied to international perceptions of Haiti itself, have positioned Little Haiti as a site in need of revitalization and top-down reinvestment into the neighborhood. In the official channels, Miami's former African American commissioner, Art Teele, initiated the first city-led revitalization project for downtown Little Haiti: the Little Haiti Cultural Complex, approved in 2001 and comprised of the Soccer Park, the Cultural Center, and the Caribbean Marketplace. Projects like the Little Haiti Cultural Complex provide spaces in the neighborhood for community organizing and socializing-an undeniable resource and neighborhood improvement if the existing community could stick around to enjoy it. But in the reality of capitalist approaches to urban redevelopment and the Miami-specific climate-change gentrification, the construction of the Cultural Complex was just a drop in the rapid stream of changes rushing through Little Haiti. In hindsight, many community residents recall these years as the beginnings of the neighborhood's gentrification. Marleine Bastien recollects increased harassment and fining of residents that begun during the revitalization efforts (personal interview, 29 January 2019). The Complex opened in 2008 after several years of construction delays, and the 2008 housing market crash and subsequent recession paused the area's restructuring only briefly. Gentrification returned to Little Haiti with increased force a few years later. In the recent years, new developments and private investments sprouted thought the neighborhood, encouraged by the relatively inexpensive land prices and real estate speculations driven by the threat of rising sea levels.

${ }^{20}$ Cindi Katz defines social reproduction as "the biological reproduction of the labor force, both generationally and on a daily basis" (7). 
Responding to this onslaught of change brought in from the outside, the community sought to formalize their cultural mark on the neighborhood with an official "Little Haiti" designation in 2016. This campaign centered a struggle about the cultural identity of the neighborhood. In this round of the fight against gentrification in Little Haiti, the community's efforts aimed to ensure that-at the very least-the city officially recognized the important contributions of Haitian Americans in the making of Miami. Following years of contentious debates and lobbying led by Bastien, Metellus, and Joann Milord among others, the City of Miami voted in support of the designation in May of 2016. For many community members this decision represents a tangible win that the community could hold onto amidst imposed transformations. But some view it as an empty gesture intended to appease the Little Haiti community. ${ }^{21}$ Yet others highlight how the deal required a territorial compromise, which affects current negotiations with developers. The official outline of Little Haiti between 54th Street to 79th Street and Northwest 6th Avenue to Northeast 2nd Avenue reflects a loss of territory to the encroaching Design District. This trimming of Little Haiti boundaries opened up a loophole for developers to exploit when negotiating with the city. Representatives for the Eastside Ridge SAP, for instance, attempted to dismiss any challenges raised by Little Haiti-based organizers as irrelevant, arguing that their project is planned for the outskirts of the official Little Haiti outline. ${ }^{22}$ The commissioners' decision has also not prevented a smaller development-The Citadel Miami Food Hall-from simply replacing the name Little Haiti with the obsolete Little River throughout all their marketing materials. ${ }^{23}$ Nevertheless, the Little Haiti official designation campaign illustrates one of many community-driven efforts to institutionalize versions of Haitian identity in Little Haiti's social and built environments. Two women-led organizations, Northeast 2nd Avenue Partnership (NE2P) with Joann Milord as Executive Director and the Little Haiti Cultural Complex (LHCC) under the leadership of Sandy Dorsainvil have been at the forefront of promoting Haitian culture to drive neighborhood revitalization. But beyond the community-centered initiatives and the public-private partnerships lies the top-down exploitation of Little Haiti's culture as a means to capitalist gains; a process exacerbated by the recent concentration of Special Area Plans (SAPs) in the neighborhood.

The consistent and strategic organizing of other community killjoys has begun to shift the discourse around SAPs among city officials and the broader narratives around housing in local media. SAP is a provision named after a section of the Miami 21 zoning code which allows developers who assemble nine consecutive acres of land to apply for a land-use change. This change typically amounts to massive upzoning (building higher and at increased density). The city offers this zoning flexibility in exchange for undefined public benefits usually negotiated between the developer and the city planning staff. What is astounding is that developers can meet the public benefit requirement by simply providing green or open spaces. In other words, as currently written, the SAP provision does not require developers to provide affordable housing or an analysis of displacement impacts. According to Miami-based attorney David Winker, this framework leads to concentration of new large-scale luxury developments in minority neighborhoods "where land is still cheaper and can be aggregated more easily." As reported by Winker, a recent article in the Journal of Affordable Housing and Community Development Law concludes that "Miami 21 [SAP provision] has resulted in "displacement [of the poor] to outer fringes," "increased gentrification," and greater "social/economic segregation" because when people are forced to move they tend to move to areas that are more segregated." Magic City Innovation District is only one of three developers who have asked for approval of a Special Area Plan in Little Haiti in the last two years. ${ }^{24}$ Concerned about the impact of this concentration, women organ-

\footnotetext{
${ }^{21}$ For many stakeholders in Little Haiti the name change is only a matter of time. Martin Nandy, known in the neighborhood as "Captain Haiti" and the director of "Keep it Haitian" Vendors Association, feels the symbolic wins are indicative of the accelerated gentrification of the neighborhood: "Very often those in power will give us symbolism instead of real benefits to appease us, to silence us, to prevent us from rocking the boat. It's an old power tactic. Who cares if it's called Little Haiti if you don't own it? It's about ownership. A collective ownership. People who are moving here now with gentrification have their own culture that they will want to impregnate into the neighborhood. They won the place, so they will change the name when their time comes" (personal interview, 7 January 2019). Jan Mapou echoes Martin's concerns about the lifespan of the Little Haiti name. As an owner of several parcels of land in the neighborhood, Mapou has access to investors' meetings. During one such meeting-Mapou told me-a developer leading the meeting shut down a debate about the urgency of renaming Little Haiti to Little River or Lemon City by stating, "let's change the place first; we can take care of the name once we are done" (personal interview, 2 February 2019).

${ }^{22}$ Eastside Ridge SAP seeks to build a 22-acre mixed-use complex of 14 buildings and a total of 5.4 million square feet. Like the Magic City SAP, the developers propose to put $\$ 10$ million into a community trust. Developers have been seeking approval from the City commission concurrently with the Magic City SAP, but the Eastside Ridge proposal has been delayed five times (Rodriguez).

${ }^{23}$ The Citadel is 62,000 square feet with restaurant vendors, bars, retail space, makerspace, and a rooftop lounge. The space opened in February 2019 (Valys).

${ }^{24}$ Magic City, Eastside Ridge, and Citadel.
} 
izers with FANM, lawyers with the Community Justice Project, as well as other community attorneys, have called for an SAP reform or even repeal over the span of multiple commission hearings. Their efforts have not gone unnoticed. The Planning, Zoning \& Appeals Board (PZAB) that advises the city commission voted during the December 4, 2019 meeting to recommend a repeal of the special area plan category from the Miami 21 zoning code. The PZAB-advised changes, now considered at the city commission level, build upon the recommendations submitted in writing and repeatedly voiced by the killjoys. At the preliminary discussion meeting, board member Anthony Parrish said that multiple SAPs, "hold Miami neighborhoods under siege" (PZAB meeting, 20 November 2019). The language of violence, pressure, and forced surrender strikes as fitting to describe the takeover of Miami's low-income neighborhoods by large-scale luxury development, especially considering that the city commission has also approved the mega-project Miami Jewish Health Systems SAP in December 2017.

The recent controversies surrounding SAP approvals in Little Haiti reveal procedural flaws that are socially irresponsible, fuel Miami's already rampant affordability crisis, and favor the developer's interest over the community's needs. The Magic City SAP was approved at 3:00 am with only four of the five commissioners present. Commissioner Keon Hardemon negotiated the community benefits package behind closed doors; in exchange for generous upzoning, Magic City would provide \$31 million, paid over 15 years, to the Little Haiti Revitalization Trust. This trust agreement was approved by the Commission in place of, not in addition to, the previous community benefits package that required affordable and workforce housing on site. The trust is to be governed by a five-person board: the Miami City Manager will appoint one member, and the other four will be named by the city commissioner for District 5, at this time Keon Hardemon, the same commissioner who negotiated the deal (Commission hearing, 28 February 2019, 28 March 2019, 27 June 2019). Those Little Haiti women leaders who voiced support for the Magic City project advanced arguments about social benefits that could trickle down to the community from private investment and economic development of the neighborhood. Other women organizer, as I outline below, take this position to task. Many activists challenge the developer's and commissioner's reassurances that the trust offers a better deal than the initial offer.

Magic City SAP distinguishes itself from some of the other developments in part via cultural branding. Both Eastside Ridge and The Citadel Miami Food Hall insist on location names that disassociate their projects from the space of Little Haiti. Unbothered by community backlash, Urban Atlantic Group continues to market Citadel Miami, which lies within Little Haiti proper, as located in Little River. There is tragically

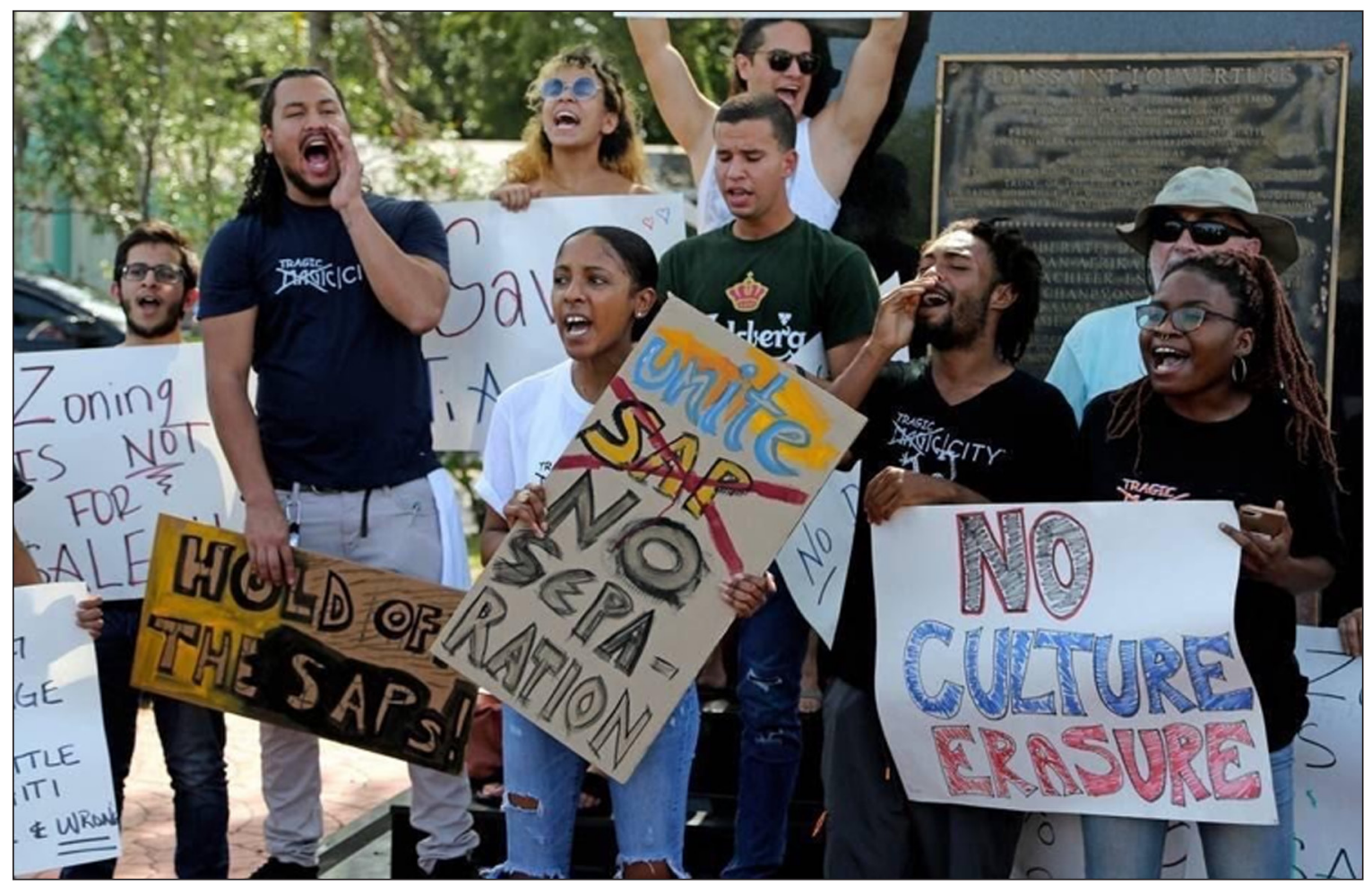

Rally against displacement in Little Haiti prior to the final Magic City vote in June 2019: Jessica Saint-Fleur, Engage Miami (far right) and Sagine Taluy, FANM (center), June 2019. Photo courtesy of FANM. 
unrealized irony in the way Citadel takes its name from the revered symbol of black resistance-Citadelle Laferrière fortress, proclaims itself a "fortified stronghold for culture and community," and featured Haitian folk dancers during the opening block party while casting off association with Haiti and actively participating in cultural erasures in Little Haiti (Francois). ${ }^{25}$ In this simultaneous appropriation of Haitian heritage and strategic distancing from Little Haiti, Citadel offers perhaps the clearest local example of cultural branding that has gone terribly wrong.

Magic City has committed no such blatant cultural erasures. Their marketing materials consistently highlight Haitian culture as a valuable resource. In fact, on its face Magic City's cultural branding efforts appear robust, attractive, informed, well-intended even. The developer announces that "celebration and preservation of the thriving Caribbean culture in Little Haiti is the foremost priority of the project" (Magic City website). Tellingly, this claim mimics the language of "presentation" and "preservation" at the heart of the initiatives within the community, such as the Little Haiti Cultural Center's mission statement. To distinguish themselves from other developers and gain community buy-in, Magic City has coordinated their outreach initiatives with local artists and arts promoters. Among their cultural events, the "Route 1804: Little Haiti, Heartbeat of the Caribbean" exhibition at Art Basel 2017 was conceptualized by Sandy Dorsainvil, then working as a consultant for Magic City. The developer's "open houses" in particular were promoted and defended as the developer's effort to reach the community and solicit their input. Yet many argued these events took a form of upscale, show-like exhibits tailored only for the more affluent residents in the area. Because Magic City has clearly consulted with cultural insiders such as Dorsainvil, the ways in which their materials and initiatives manipulate Haitian culture to appeal to potential buyers comes across as much more subtle, less appropriative, more forgivable, and even laudable- to some. The leaders and organizers who spoke out in support of the project are killjoys in their own right as they get in the way of organic solidarity and assumed community agreement (Ahmed 14). Other community organizers describe Magic City's outreach initiatives as "very tone deaf."(Taluy, personal interview 4 November 2019). Marleine Bastien emphasizes how the open houses excluded most of the working-class people who live in Little Haiti not only because the community members work long hours, but simply because the upscale format was alienating to lower income folks (personal interview, 3 March 2019). Another organizer with FANM, Sagine Taluy, adds: "they provide these events and amenities as a benefit, but most people here, especially the new immigrants, might not even know how to make use of them" (personal interview, 4 November 2019). At the center of FANM's critique here is that the developer uses Haitian culture as a "selling ticket" while excluding a large portion of the community who created this culture in the first place. Taluy sees parts of cultural branding as "really kind of disgusting" when considered in the context of Haiti's colonial history of stolen resources (personal interview, 4 November 2019).

I argue that the images Magic City produces flatten unique cultural details into broad stereotypes, perpetuating the same damaging narratives that have fueled the irresponsible redevelopment of systemically disinvested neighborhoods for decades. For example, in its shout out to Notre Dame, Magic City's website features the recently renovated church as a tourist attraction in the "points of interests" section. Magic City highlights the Catholic church alongside other edgy yet palatable to middle-class taste "cultural sites" in Little Haiti, including Yo Space arts studio, Churchill's Pub, Panther Coffee, and several multiethnic restaurants. Little Haiti's botanicas and the neighborhood's many storefront churches are tellingly absent from the developer's mapping. Exclusion of these diverse places of worship whitewashes the unique landscape of Haitian spirituality. To allow the recently renovated and beautifully landscaped Catholic church to singularly represent the religious life in Little Haiti subdues the spiritual dimension of Haitian culture in similar ways that fusion restaurants in gentrifying neighborhoods subdue the flavor of ethnic cuisines to make them more palatable to broader audiences. This beautiful architectural site can be easily enjoyed by local and foreign tourist audiences hungry for authenticity of experience but unaware of any broader context, history, or geography of the community.

While Magic City uses the unique elements of Haitian culture to create cultural experiences, their landscapes are both exclusive of the working-class, and paradoxically contingent on the narrative of a homogenous working-class community in need. Representatives of the Magic City project appreciate Little Haiti's cultural significance mainly for providing the neighborhood with "incredible growth potential." Their

\footnotetext{
${ }^{25}$ Citadelle Laferrière, also known as Citadelle Henri Christophe after the leader of the Haitian slave rebellion, was constructed by him after Dessalines declared Haitian independence and meant to protect the new nation from attack by the French. It is now a UNESCO World Heritage Site. http://citadellelaferriere.com/
} 
depictions interlace celebration of Haitian culture with representations of a closed-off neighborhood whose residents are assumed to lack the necessary expertise and competence to manage their cultural resources and transform their own environment. Positioning cultural richness as a mismanaged resource, developers take it upon themselves to provide the vision and capital to attract "artists, creatives, entrepreneurs, and makers to our community" who can help Little Haiti "become a more desirable and recognizable neighborhood" (Magic City website). To promote their vision of community uplift, Magic City provides unspecified "support" to local initiatives and institutions, including the Sounds of Little Haiti monthly festival, Little Haiti Football Club, Notre Dame, and the famed Little Haiti muralist Serge Toussain. The actual and perceived benefits of these initiatives have won over significant community support for Magic City. But the framework of condescending benevolence described above reinforces a dangerous notion that vertical (topdown) development is necessary to the progress and well-being of Little Haiti. Promising the trickle-down uplift for Little Haiti as a culturally rich but disinvested community, Magic City trains their audiences to accept displacement as the inevitable cost of "progress."

\section{Killjoys Keeping Tempo}

Cultural branding in Little Haiti is a catch-22 situation. Because the government has failed to provide proper services and infrastructure in the neighborhood, and due to Miami's tourism-oriented economy, the community needs tourists and outside investment to survive. At the same time, the growing outside interest and recognition of the neighborhood's cultural assets forecloses the possibility of survival by making the area increasingly unaffordable and culturally alienating to the economically vulnerable segments of the Little Haiti community. Branding Little Haiti relies on the twofold undertaking of cultural preservation and presentation, which most hope will result in Little Haiti's economic uplift. But these branding opportunities also expose tensions within the group of killjoys who advocate for Little Haiti's autonomy and economic prosperity. Everyone I talked to agrees that the neighborhood needs investment, that people deserve to live in a safe space with suitable roads, clean parks, and decent housing and business opportunities. But there is no consensus about how to reconcile these desires with the need to protect Little Haiti's status as a springboard neighborhood for newly-arriving immigrants, or whether this legacy can or even should be maintained in the push for the area's economic uplift. On the business-oriented, entrepreneurial side of the argument, there are discussions of an "unstoppable process" that inevitably produces winners and losers, and of cultural preservation as the best way to mitigate these impacts. On the other side, there are voices demanding a systemic change to ensure an equitable and inclusive development that does not leave behind the most economically vulnerable groups (City of Miami Commission Hearing-Planning \& Zoning, 15 November 2018). Women on both sides of the Magic City debate assert their positions as rightful participants in the politics of the city. Despite the differences in outlooks on this particular project, their active involvement in the SAP approval process challenges the presumed incompetence of community members on the issues of urban restructuring. These women strategize and consistently show up, requesting that the developer and the commission include residents of Little Haiti in the planning process to better demonstrate how the zoning codes and dollars translate to the actual livelihoods of people, to the well-being of families, and prosperity of businesses.

Within Miami's tourism-oriented economy and the city's politics of multiculturalism, a level of outsourcing of the neighborhood's symbolic resources seems necessary when competing for grants and other forms of economic support beyond the city budget. The Big Night in Little Haiti, later dubbed Sounds of Little Haiti, a key event in the Little Haiti Cultural Center's programming, perhaps best illustrates this challenge of appealing to general audiences to attract investment to a neighborhood that needs it without a mainstreaming of culture that developers can easily exploit for profit. As a staple of LHCC cultural branding programming, the Sounds of Little Haiti has been envisioned and marketed as a draw for visitors from the city and beyond. But LHCC, alike other city-owned cultural institutions, faces constraints and pressures when seeking funding for local programming that benefits the immediate local community. In 2011, Laura and Jim Quinlan of the Rhythm Foundation secured a \$125,000 grant from the John S. and James L. Knight Foundation's Knight Arts Challenge Program and partnered with the Little Haiti Cultural Center to host a monthly free outdoor event entitled Big Night in Little Haiti that could "bring new attention and activity and broaden the interaction between Little Haiti and the broader South Florida communities" (Martin). ${ }^{26}$ When

\footnotetext{
${ }^{26}$ The Rhythm Foundation is a non-profit cultural organization founded in Miami Beach in 1988 focusing on international music www.rhythmfoundation.com/about/. The Knight Foundation is a national foundation investing in the arts in cities "where brothers John S. and James L. Knight once published newspapers" https://knightfoundation.org/about/.
} 


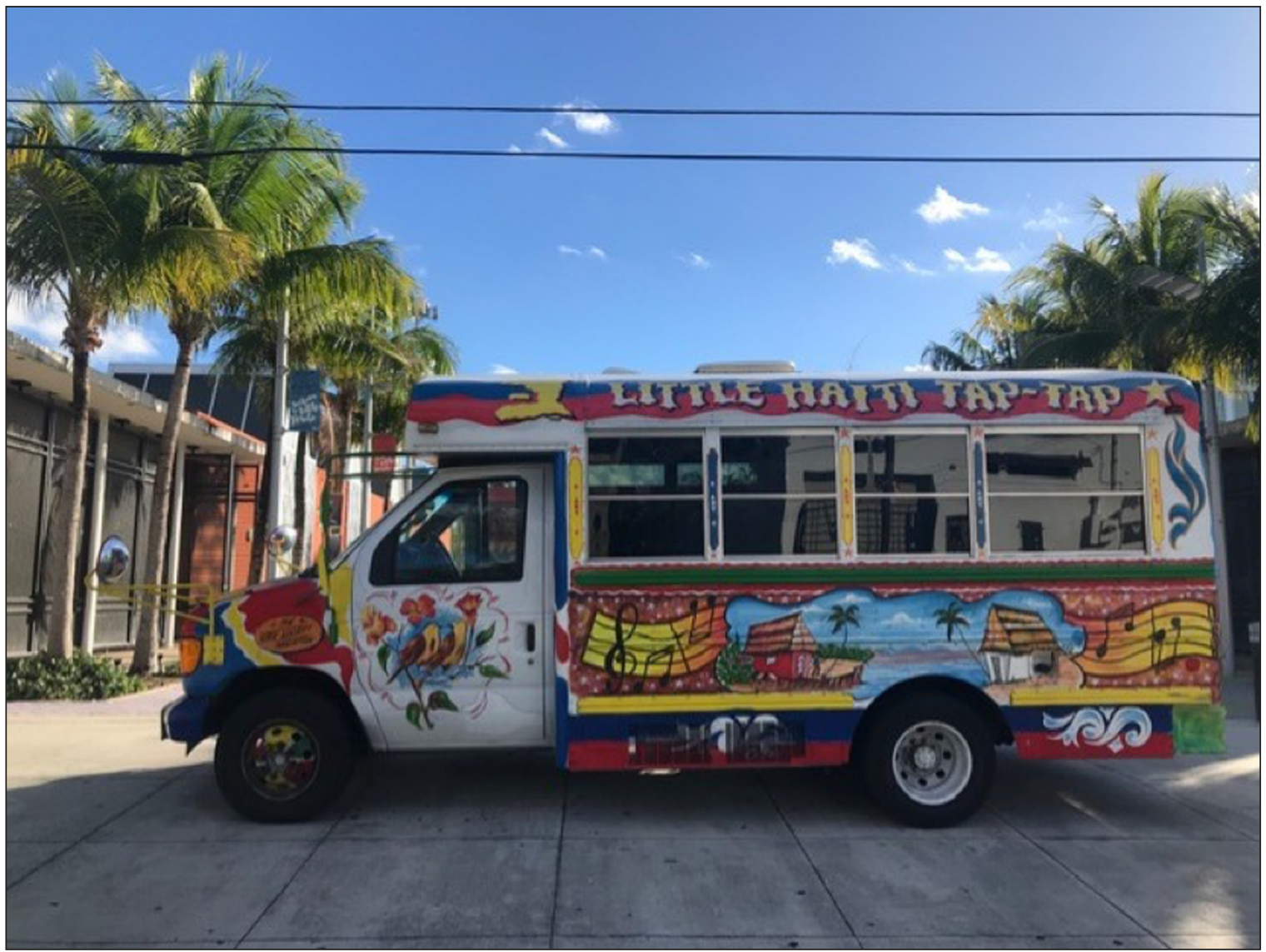

Little Haiti Cultural Center's Tap Tap bus-Haiti's traditional share taxi-parked in front of the courtyard. The center uses it to promote tourism in Little Haiti. Photo courtesy of the author.

the Rhythm Foundation funds ran out in 2016, the monthly cultural celebration discontinued. Following her wrongful termination from LHCC in the same year, Sandy Dorsianvil continued to promote Haitian culture through private ventures with her firm Maximillian Consultants Inc. and as a community liaison for Magic City. ${ }^{27}$ In this role, she was in charge of community outreach, connecting the developer to people in neighborhood and facilitating cultural events to get the community members involved in the project. Thus, Dorsainvil brought the annual event back under the name Sounds of Little Haiti and co-produced the event with the Center using private sponsorships. Among other sources, Sounds of Little Haiti received financial support from Magic City. Magic City has leveraged this sponsorship to both promote their project and prove their charitable and preservation work in Little Haiti (Magic City website). My intention is not to vilify cultural branding initiatives like the Big Night/Sounds concert programs, but to reflect critically on whether they provide the right shield against cultural erasure and inequitable neighborhood redevelopment in Little Haiti. Outward facing projects that prioritize attracting visitors and new residents are risky in the reality of ever-shrinking and costly Miami real estate and the still limited political influence of Haitian Americans in the city. However well-intended and well-received, such cultural branding initiatives frequently wind up feeding the monster they aimed to defeat.

Magic City's support for cultural initiatives provided them with talking points about "community benefits" for commission hearings, clouding a discussion of the type of benefits that the community actually needs. Such initiatives allowed the developer to reconcile in the public eye two goals that in reality are mutually exclusive: to protect the thriving Haitian culture and maintain community presence in the neighborhood and to expedite the approval process for the massive luxury Magic City SAP, which-as even those supporting this SAP admit-will inevitably change the culture and demographic composition of Little Haiti (Commission Hearing, 27 June 2019). As an arts promoter, Sandy Dorsainvil has prioritized preservation of Little Haiti's

${ }^{27}$ Dorsainvil was reinstated as the LHCC director in the fall of 2019. For more information about her wrongful termination and clearing of her name, visit: www.miamiherald.com/news/politics-government/article230256139.html. 
cultural footprint, especially in the face of encroaching gentrification. For Dorsainvil, the brightest possible future for Little Haiti is filled with Haitian arts: "I would want for Little Haiti to become a mecca for AfroCaribbean culture" (personal interview, 20 November 2019). In their ambitions for Little Haiti, the City of Miami and Magic City seem to share in at least a portion of this goal. But while their cultural branding of the area relies on the marketable but disembodied cultural elements manicured for the enjoyment of tourists and potential, more affluent, new residents, Dorsainvil's vision centers the people of the Haitian diaspora; as homeowners and business owners, Haitian Americans become beneficiaries and consumers of the culturedriven improvements and not just as producers of the consumable content. In Dorsainvil's capacity as director of LHCC, she helped to develop diverse and culturally significant branding initiatives such as African dance classes, the Little Haiti Book Festival, or the Little Haiti tours. ${ }^{28}$ Dorsainvil also stands by her work for Magic City and describes the developers' cultural branding efforts as positive and potentially uplifting for the neighborhood's image and stability. She states, "I was proud to be a part of that. I could go to bed at night and my conscious was clear ... I might be wrong ... Later on, I might look back and say: what the heck? But today, yesterday, a week ago, I feel good about it" (personal interview, 20 November 2019).

The Magic City SAP has proven particularly contentious in exacerbating pre-existing divisions within the Little Haiti community. Those who fought side-by-side on issues of immigration, racism, and Little Haiti's official designation, have found themselves standing on the opposite sides of the City Commission chamber weighing the Magic City proposal. These divisions unfolded in particularly vivid ways during three commission hearings in 2018-2019 and two city-mandated community meetings with Magic City in the spring of 2019, particularly in the evolution of the Concerned Leaders of Little Haiti-a group of community and faith-based organizations and leaders founded to unite community representatives in negotiations with the developers. Organized by FANM with the legal counseling of the Community Justice Project, Concerned Leaders demanded a community benefits package that would prioritize on-site affordable housing, job training and job priority for Haitian residents, community trust funds, and community involvement in the development process. But the discussions resulted in an internal rift before the November 2018 hearing. A majority of the organizations and leaders within the group decided to extend their support for the Magic City SAP at the incoming commission hearing even though the developer refused to meet the Concerned Leaders' initial demands. During the final commission hearing in June 2019, Sandy Dorsainvil spoke in support of the project. Aware of the "the good, the bad, and the ugly of this deal," she insisted that the community benefit package represents "more than anyone has ever done for us" (City of Miami Commission hearing, 23 June 2019). Rosslyn Wuchinich, Gepsie Metellus, and Leonie Hermantin share in her sentiment. Their organizations propose that to support Magic City and capitalize on the Magic City Community Trust fund offer presents the only opportunity for Little Haiti to thrive through the inevitable gentrification (City of Miami Commission Hearing-Planning \& Zoning, 28 March 2019). This support was not extended without hesitation or discomfort. Many of the project's community supporters do acknowledge how the grand scale of the Magic City SAP is sure to alter the landscape of Little Haiti and exacerbate the issues of cultural and material displacement in the neighborhood. Even Dorsainvil is reluctant to proclaim the commission's decision as a straightforward win for the community: "it's to be seen," she says, adding "on the surface it's a huge win. No community has ever received that kind of money up front. Now it's just a matter of who's going to be included in the process" (personal interview, 20 November 2019). Moreover, this position in support of the Magic City SAP has created deep affective tensions. During the February commission hearing, Leonie Hermann pointed out that speaking out against the grain of anti-gentrification social activism risks accusation of selling out to the developer: "It's clear that all the supporters of Social Justice have been extremely intolerant about people with whom they disagree, and those of us who've taken the courage to speak on behalf of the project have been labeled as people who've taken bribes, who've taken money under the table" (City of Miami Commission Hearing-Planning \& Zoning, 28 February 2019).

What Dorsainvil sees as a hopeful unknown, to Community Justice Project, FANM, Engage Miami and other anti-gentrification organizers is a clear deal breaker. Women on the opposite side of the Magic City debate passionately disagree with accepting the deal just because something is better than nothing-a premise they perceive as a "beggars can't be choosers" mentality. This prompted FANM, Community Justice Project, United We Dream, Poetry Collective, and Engage Miami to leave the Concerned Leaders group. Marleine

\footnotetext{
${ }^{28}$ The Little Haiti Book festival is an annual event that takes place in May to promote writers, booksellers, and performers from Haiti and the diaspora. The event has been held for seven years as of May 2019 and it is co-sponsored by the Miami-Dade College's Miami Book Fair, Sosyete Koukouy of Miami, Inc. and Mapou Cultural Center.
} 
Bastien recalled this evening to me with visible sorrow: "We organized civil meetings, provided food for the group, and at the last minute we had to recede from it...It was really painful, but it was either that or stand with them and say we agree for the process to move forward even though Magic City did not give us what we wanted" (personal interview, 29 January 2019). Taluy views the argument of the Magic City supporters as starting from the position of compromise:

I find the argument that you need to compromise to get a seat at the table irresponsible because you shouldn't allow anyone to come into your community and even create a table, you should always be at the table. When they come, they are coming to your table not the other way around. I think that FANM's position is that "This is our table and so if you come to take a seat at OUR table come responsibly, come respectfully, and then we can have a discussion. (personal interview, 13 November, 2019)

While agreeing that development and movement of people cannot be stopped, Taluy argues that the uneven dynamic of who is most sponsored and most excluded by the development can and should be challenged. Throughout our conversation, Taluy described as "irresponsible" and "defeatist" those arguments that accept displacement of the most vulnerable communities as a natural, if regrettable, side-effect of progress.

To a certain extent, the split in the community organizing tactics reflects generational differences. Young people overwhelmingly spoke against the Magic City project, presenting arguments that were as passionate as they were well-researched and articulate. It was mostly during the city-ordered community meetings (which, notably, no city representative attended) that FANM, Community Justice Project, and Engage Miami challenged the discrepancies between Magic City's self-presentation as the culturally sensitive good guys of private development and the inadequacy of their benefits package and their dismissal of community input. Women organizers within these organizations pointed out the hypocrisy in the way Magic City proclaims preservation of Haitian culture a top priority while developing eighteen acres of land, previously housing the Magic City trailer park, into a luxury mixed-use development with no on-site affordable housing. They also confronted the developer's benevolence as patronizing, as well as exposed the ignorance of Magic City's cultural branding approaches. During the first city-mandated community forums at Notre Dame, Magic City opened up with a presentation of their project. The virtual rendering of the Magic City SAP design showcased French street names as an example of the developer's preservation efforts and of tribute to the neighborhood's thriving Haitian culture. In response to this demonstration, Engage Miami organizer Jessica Saint-Fleur remarked to the loud applause of the gathered audience: "The names that you are proposing for this project, these French names ... yeah that is a gross depiction of Haitian culture ... that is in fact not Haitian culture; you're talking about French culture. The French, you know, who were our colonizers" (Magic City Community Meeting, 23 April 2019). Saint-Fleur challenges the developer's cultural branding as lacking proper understanding of the linguistic complexities at work in Haitian history- of how language bears on the socio-political and economic dynamic and divisions on the island and in the diaspora. It was lost on Magic City that French has been the language of choice and distinction of the Haitian elite and that the Haitian people long fought for appreciation and official recognition of Kreyol. The gaffe of this proposal was the more pronounced as it was uttered at Notre Dame, which to this day holds masses only in Kreyol and English. ${ }^{29}$

Jessica Saint-Fleur is a part of the larger wave of young people's activism for housing justice in Miami that made itself visible during the Magic City negotiations. Saint-Fleur grew up in Little Haiti, moved away for college and, unlike many in her cohort of the second-generation Haitian Americans, returned to Little Haiti to "give back to the community" (informal interview, Magic City Community Meeting, 23 April 2019). During our brief conversation, she shared her initial reluctance to return to Miami-a city, which she felt had limited opportunities for her ambition and little living space for her pockets. Yet here she is, canvasing in the community and standing side-by-side with women who have long organized around the issues of housing in Little Haiti to be the voice of the younger generation of women in the struggle against inequitable development. The organization she represents, Engage Miami, prioritizes the perspective of young people growing up in Miami's gentrifying neighborhoods or trying to reclaim their right to the city upon returning from college. The Engage Miami website states that "Millennials and Gen Z increasingly see housing as a top issue

\footnotetext{
${ }^{29}$ Years back, Monsignor Thomas Wenski, one of the church's founders, expressed his solidarity with his early Haitian parishioners "by not learning French" (Rey and Stepick 34).
} 
hampering their ability to thrive." Yet many older Little Haiti residents supporting Magic City, the developer's lawyer, and some of the commissioners themselves disparaged the young community organizers as an overly-emotional noise makers. These attacks rarely engaged the activists' arguments, but rather pointed out the young age, overly zealous tone, and the killjoys' refusal to let go.

Other community members invoke the opposite offense of the second generation: young people's disinvestment and lack of attachment to place. When asked about the role of second generation Haitian American in efforts to sustain Little Haiti, Jan Mapou said, "as for the ambitious, educated, and talented young people of Little Haiti, they don't feel the same attachment. With few exceptions, they don't want to come back to the overpriced Little Haiti" (personal interview, 2 February 2019). Mapou's comments reflect what many describe as the Caribbean problem of Miami: all the young local talent leaves, partially because the city demands so much and offers so little in return, but also because those who constitute Miami's multiculturalism do not recognize themselves in the stories told about their city. Women on both side of the Magic City debate have expressed joy at seeing young people participating in the project, striving to change the conversation, to influence the process that seems increasingly dated.

The differences in approach among the Magic City killjoys reflect two schools of resistance: one that seeks a seat at the table and emphasizes the importance of representation within the existing power structure, and one that seeks to upend that very table (personal interview with Meena Jagannath, 16 May 2019). There is a long history of systemic neglect that has brought us to a moment when the Little Haiti community finds itself at a shaky table with little negotiating power. Understanding that decades of systemic neglect has put Little Haiti in a dire need of investment, Magic City has issued threats of pulling the offer because of the community pushback. Such tactics often intimidate city officials who care about the dollar amounts flowing into their districts. For these reasons, city commissioners are inclined to side with the developer even if it is not in the best interest of their constituents. When women organizers push the commissioners on this logic, when they continue to challenge the developers and city officials, they are interrupted, talked over, dismissed, or even threatened. A particularly heated exchange occurred between Marleine Bastien and Keon Hardemon during the February 28, 2019 City of Miami Commission Hearing when FANM attempted to obtain an intervenor status. ${ }^{30}$ During that meeting, FANM strongly opposed the deal commissioner Hardemon negotiated with Magic City and revealed to the public and other commissioners at that meeting without previous notice. In response to FANM's opposition Hardemon, on a few separate occasions, confrontationally brought up funding FANM receives from the city for poverty relief efforts (implying the organization might be misusing the funds). He also threatened to remove FANM members from the room (City of Miami Commission Hearing-Planning \& Zoning, 28 February 2019). Hardemon also issued intimating statements directed at the CJP attorneys representing FANM, specifically Meena Jagannath, suggesting that their bar licenses might be at risk. Members of the public on both sides of the conflict found Hardemon's comments addressed at Marleine Bastien concerning, so much so that the public comments that followed the exchange each began with either a short tribute to Bastien's long-time work in the community or a calling out of the commissioner's behavior as "shameful," "disgusting," and "ridiculous." Among many others, Laura Munoz with the Florida Immigrant Coalition said: "I would like to also talk about my concern about the way that Marleine was treated today by this Commission. It was ridiculous, and all of those men should be ashamed" (City of Miami Commission Hearing-Planning \& Zoning, 28 February 2019). These exchanges reveal the willful work it takes to intervene in the order of masculinist politics of urban planning in the city. Bastien, and the other killjoys failed to be happy about the newly negotiated deal. They got in the way of the commissioner's happiness. By pointing out the shortcomings of the community benefit agreement, by asking uncomfortable questions about the process, by uncovering the ugly underbelly concealed under the neatness of dense legal jargon, they refused what Ahmed calls the "happiness script" (265). And for that refusal they were attacked as ungrateful (for the city support to their causes) and damaging (to the civility of the process), and difficult for the sake of being difficult. During public comment, community members are required to address the city commission "in a respectful manner"; no such official protections are extended to the women advocates. As mentioned earlier, the killjoys helped to change the discourse about housing in Miami. "There can be joy in killing joy" after all, as Ahmed tells us (15). But willfulness and insistency in organizing comes at a mental and emotional cost of having your reputation questioned and motives challenged

\footnotetext{
${ }^{30}$ Intervenor status is provided to organizations or individuals who can demonstrate they are adversely affected by the development
} in a manner greater than the general public. 
in the public arena, often by men in power. Despite the tensions and many difficult exchanges, all the women I've talked to are hopeful that the community will find common ground, and come together to organize for larger systemic changes, like the overhaul of the broken SAP process.

\section{A Woman's Work...}

"I always tell people: you have to be a part of the process; you have to impose yourself. Because if you are waiting to be invited to the dinner party, the invitation might never make it" Sandy Dorsainvil told me during our interview meeting at her recently-reinstated LHCC office (personal interview, 20 November 2019). The women organizers who populate the pages of this essay all assert their right to participate in the making and remaking of Miami, representing and empowering those traditionally sidelined in urban planning-young people and women of color. Women in these organizations might differ in views and visions for what is best for Little Haiti, but they all have skin in the game and sandals on the ground, and they all impose themselves on a system that was not designed to include them. This informal infrastructure of women of color advocacy for community justice in Little Haiti consists of long-term residents who have lived and worked in Miami for years, those who moved away but still have organizational and affective ties to neighborhood, those relatively new to the area who hail from the Caribbean via New York or Toronto and who have recently made Little Haiti their home, and those who grew up in Little Haiti, moved away for college, and now seek their way back into the neighborhood. Through this lens of an eclectic, multigenerational, and multiethnic grassroots organizers, Little Haiti emerges as a heterogenous, entrepreneurial, and civically-engaged neighborhood. Attending to these complexities peels off the top layers of gentrification narratives that index Little Haiti via the simplistic tropes of poverty or consumable difference. In the frameworks of cultural branding, Little Haiti charms with the bright colors of Northeast 2nd Avenue's gingerbread architecture, the smell and tastes of Haitian goods at the Caribbean Marketplace, and the sounds of konpa reverberating through the Cultural Center's sprawling courtyard every third Friday of the month. Developers manipulate these marketable, disembodied cultural elements to advance the type of development that leaves the city inaccessible to a large number of its immigrant populations. Women organizing for community justice in Little Haiti embody the efforts to change the narratives and the realities of just who gets to and how they get to enjoy the multicultural magic of Miami.

But as these women "impose themselves" as a political force in Miami's development through their roles as city employees, community leaders, attorneys, or young activists challenging the elected officials or powerful wealthy men of the private industry, they too often find themselves interrupted, disrespected, cast off as noisemakers, or fired. Applying a gender-sensitive lens to the politics of development and community justice in Little Haiti reveals then also the splintered landscape of Miami's development politics: the informal infrastructure of organizing for community justice driven by women of color within the male-dominated formal politics. In the Mexican American Women Activists, Mary Pardo writes, "Different from electoral politics, grassroots activism happens at the juncture between larger institutional politics and people's daily experiences. Women play a central role in the often-unrecorded politics at this level" (Pardo 32). If we try to explain this feminization of grassroots organizing that Pardo outlines and the women in this essay embody, we might turn to the women's position as key community informants, or to the female inclination to nurture both the family and its natural extension-the community. We might also choose to see this tireless work of women of color as empowering. But, as Pardo suggests, this "unrecorded" labor is often unpaid or underpaid, and paved with sacrifice of family time, self-care, wealth acquisition, and building up careers at a crucial time in life. The sacrificial narrative that underpins assumptions about community organizing, particularly around the issues of housing, tends to perpetuate circumstances that have created this imbalance in the first place. The work of community organizing is not only labor intensive, it is also all-consuming and emotionally draining. Those who find themselves repeatedly standing in the commission chamber and challenging the status quo in what seems like perpetuity, feel exhausted. ${ }^{31}$ Those who speak up for what in their heart of hearts feels right only to face attacks of selling out to the developer describe the experience as painful. As organizers for equitable development in a city that consistently ranks as one of the world's least affordable places to live, these women inevitably become killjoys. And the work of a killjoy is as unappreciated as it is necessary.

\footnotetext{
${ }^{31}$ In my conversations with Jagannath, Taluy, and Bastien, all three women discussed the emotional toll of continuously challenging the status quo of government-sponsored irresponsible development that drives displacement (especially as their work is being dismissed as "resisting for the sake of resistance").
} 


\section{Acknowledgements}

Special thanks to the Magic City killjoys for their tireless advocacy and for the time, knowledge, and inspiration that they offered to this essay. As always, I am most grateful to Tim Watson and Donette Francis for their critical questions, advice, and mentorship over many years. A warm thank you to Allison Harris and the anonymous reviewers for their constructive criticism and generous editorial guidance that has been invaluable in the revision process.

\section{Competing Interests}

The author has no competing interests to declare.

\section{References}

Ahmed, Sara. Living a Feminist Life. Duke University Press, 2017. DOI: https://doi.org/10.1215/9780822 373377

Alvarez, Camila, and Natalie Edgar. Right to Wynwood. 2013. vimeo.com/110682099.

Bandell, Brian. "City Commission approves Magic City development in Little Haiti." South Florida Business Journal, 28 Jun 2019.

Bastien, Marleine. Personal interview. 29 January, 3 March 2019.

Bondi, Liz. "Gender Divisions and Gentrification: A Critique." Transactions of the Institute of British Geographers, vol. 16, no. 2, 1991, pp. 190-198. DOI: https://doi.org/10.2307/622613

Cahill, Caitlin. "At Risk? The Fed Up Honeys Re-Present the Gentrification." Women's Studies Quarterly, vol. 34, no. 1-2, 2006, pp. 334-363.

Connolly, N. D. B. A World More Concrete: Real Estate and the Remaking of Jim Crow South Florida. University of Chicago Press, 2014. DOI: https://doi.org/10.7208/chicago/9780226135250.001.0001

Danticat, Edwidge. "The Soul of Little Haiti." Miami Herald, 29 September 2019.

Dorsainvil, Sandy. City of Miami Commission Hearing-Planning \& Zoning, 28 February 2019, Miami City Hall, Miami, FL. Public Comment.

---. City of Miami Commission Hearing-Planning \& Zoning, 27 June 2019, Miami City Hall, Miami, FL. Public Comment.

---. Personal interview. 20 November 2019.

Enarson, Elaine, and Betty Hearn Morrow. "Women Will Rebuild Miami: A Case Study of Feminist Response to Disaster." The Gendered Terrain of Disaster: Through Women's Eyes, Praeger Press, 1998.

Feldman, Roberta M., and Susan Stall. The Dignity of Resistance: Women Residents' Activism in Chicago Public Housing. Cambridge University Press, 2004. DOI: https://doi.org/10.1017/CBO9780511734977

Francis, Donette. Mapping Creole Miami: Black Intellectual and Artistic Formations, University of Miami, 20 April 2018. Opening Remarks.

Francois, Francine. "Miami's Citadel Food Hall Misappropriates a Revered Symbol of Black Resistance in Haiti." Miami Herald, 20 February 2019.

Hardemon, Keon. City of Miami Commission Hearing-Planning \& Zoning, 28 February 2019, Miami City Hall, Miami, FL. Official Comment.

Hermantin, Leonie. City of Miami Commission Hearing-Planning \& Zoning, 15 November 2018, Miami City Hall, Miami, FL. Public Comment.

Jagannath, Meena. Personal Interview. 16 May 2019.

Katz, Cindi. Growing up Global: Economic Restructuring and Children's Everyday Lives. University of Minnesota Press, 2004.

Lees, Loretta. "Gentrification and Social Mixing: Towards an Inclusive Urban Renaissance?" Urban Studies, vol. 45, no. 12, 2008, pp. 2449-2470. DOI: https://doi.org/10.1177/0042098008097099

Luscombe, Richard. "Little Haiti: will an ambitious project risk a 'diverse mecca' or revitalize it?" The Guardian, 26 October 2018.

Magic City Innovation District-Little Haiti website. 2019. https://magiccitydistrict.com.

Mapou, Jan. Personal interview. 2 February 2019.

Martin, Sebastian. "A big dream for Little Haiti." Miami Herald, 16 March 2011.

Metellus, Gepsie. City of Miami Commission Hearing-Planning \& Zoning, 28 March 2019, Miami City Hall, Miami, FL. Public Comment.

Muñoz, Laura. City of Miami Commission Hearing-Planning \& Zoning, 28 February 2019, Miami City Hall, Miami, FL. Public Comment.

Nandy, Martin (Captain Haiti). Personal interview. 07, 15, 22 January 2019. 
Pardo, Mary. Mexican American Women Activists. Temple University Press, 1998.

Perry, Keisha-Khan. Black Women Against the Land Grab: The Fight for Racial Justice in Brazil. University of Minnesota Press, 2013. DOI: https://doi.org/10.5749/minnesota/9780816683239.001.0001

Puri, Shalini, and Debra A.Castillo. Theorizing Fieldwork in the Humanities:Methods, Reflections, andApproaches to the Global South. Palgrave Macmillan, 2016. DOI: https://doi.org/10.1057/978-1-349-92834-7

Putnam, Laura. "Daily Life and Digital Reach: Place-based Research and History's Transnational Turn." Theorizing Fieldwork in the Humanities: Methods, Reflections, and Approaches to the Global South, edited by Shalini Puri and Debra A. Castillo, Palgrave Macmillan, 2016, pp. 167-189. DOI: https://doi. org/10.1057/978-1-349-92834-7_9

Rey, Terry, and Alex Stepick. Crossing the Water and Keeping the Faith: Haitian Religion in Miami. NYU Press, 2013. DOI: https://doi.org/10.18574/nyu/9780814777084.001.0001

Rodriguez, Rene. "At a Standoff? Massive Little Haiti Real Estate Development Delayed for Fifth Time." Miami Herald, 18 October 2019.

Saint-Fleur, Jessica. Magic City Innovation District Community Meeting, 23 April 2019, Notre Dame d'Haiti Catholic Church, Miami, FL. Public Comment.

---. Personal interview. 23 April 2019.

Shell-Weiss, Melanie. Coming to Miami: A Social History. University Press of Florida, 2009.

Snarr, C. Melissa. All You That Labor: Religion and Ethics in the Living Wage Movement. NYU Press, 2011. DOI: https://doi.org/10.18574/nyu/9780814741122.001.0001

Taluy, Sagine. Personal interview. 4, 13 November 2019.

Valys, Phillip. "The Citadel food hall in Miami announces opening date with 15 restaurants, rooftop bar." South Florida Sun-Sentinel, 15 February 2019.

Van den Berg, Marguerite. "Femininity As a City Marketing Strategy: Gender Bending Rotterdam." Urban Studies, vol. 49, no. 1, 2012, pp. 153. DOI: https://doi.org/10.1177/0042098010396240

Vigluccit, Andres. "The massive Magic City project wins a final OK." Miami Herald, 28 June 2019.

Walker, Alice. In Search of our Mother's Garden. Harcourt Brace, 1983.

Wilkinson, Sejour. City of Miami Commission Hearing-Planning \& Zoning, 15 November 2018, Miami City Hall, Miami, FL. Public Comment.

Winker, David, "Smart Development Requires Reform of Miami 21 and SAPs." Daily Business Review, 15 November 2019.

Yúdice, George. "Miami: Images of a Latinopolis." NACLA Report on the Americas, vol. 39, no. 3, 2005, pp. 35-39. DOI: https://doi.org/10.1080/10714839.2005.11725323

\footnotetext{
How to cite this article: Gierczyk, M 2020 Magic City Killjoys: Women Organizers, Gentrification, and the Politics of Multiculturalism in Little Haiti. Anthurium, 16(1): 10, 1-21. DOI: https://doi.org/10.33596/anth.409

Published: 31 March 2020

Copyright: ( $) 2020$ The Author(s). This is an open-access article distributed under the terms of the Creative Commons Attribution 4.0 International License (CC-BY 4.0), which permits unrestricted use, distribution, and reproduction in any medium, provided the original author and source are credited. See http://creativecommons.org/licenses/by/4.0/.
} 